\title{
Were the original Canada-US Free Trade Agreement (CUSFTA) and the North American Free Trade Agreement (NAFTA) significant policy turning points? Understanding the evolution of macroeconomic policy from the pre- to the post-NAFTA era in North America
}

\author{
Mario Seccareccia* \\ Professor of Economics, University of Ottawa, Ontario, Canada
}

\begin{abstract}
This article reviews the Keynesian/heterodox critique of free trade and the principle of comparative advantage, and offers some prima facie empirical evidence for North America that contradicts the basic predictions of the traditional free trade model. The evidence supports, instead, the view that trade liberalization actually promoted a perverse neo-mercantilist export-led growth (ELG) strategy that generates deflationary pressures not so much because NAFTA promoted greater international competition, but primarily because ELG relied on the macroeconomic role of the state in its implementing of restrictive fiscal and monetary policies to keep a lid on wage growth. The article argues that there is need for an alternative NAFTA that should promote the free circulation of goods, and that an institutional structure should be put in place that firmly ties each national government to an explicit full-employment commitment.
\end{abstract}

Keywords: free trade, comparative advantage, export-led growth, CUSFTA, NAFTA, macroeconomic austerity policies

JEL codes: $B 5, B 22, E 5, E 6, F 1, F 4$

\section{INTRODUCTION}

I was brought up ... to respect free trade not only as an economic doctrine which a rational and instructed person could not doubt but almost as a part of the moral law. I regarded

\footnotetext{
* The author would like to thank Eugenia Correa, Myron Frankman, Alain Parguez, and John Smithin for their helpful comments on the ideas developed in this article, which were first presented at an international conference on 'NAFTA after Twenty Years: Old Problems, New Challenges' at the Universidad Nacional Autónoma de México (UNAM) in Mexico City, on January 23, 2014. The author would also like to acknowledge the financial support provided by the Centre for International Governance Innovation / Institute for New Economic Thinking, and the Social Sciences and Humanities Research Council of Canada. The usual disclaimers apply.
} 
departures from it as being at the same time an imbecility and an outrage. ... I was writing that free trade was based on fundamental truths 'which, stated with their due qualifications, no one can dispute who is capable of understanding the meaning of the words.' (Keynes 1933 [1982], pp. 233-234)

Keynes's words will undoubtedly resonate with virtually any student of economics who has been exposed to the theory of free trade, via an intellectual sleight of hand, the principle of comparative advantage, from the very early years of undergraduate training. In fact, in practically every mainstream 'principles' textbook, one encounters the unchallenged and quasi-universal 'law' of comparative advantage as the intellectual cornerstone, we are told, of practically everything that is of relevance and constituting the hard core of economics. Even those mainstream economists who have chiseled around the rough outer edges of this foundation stone still point to the importance and centrality of 'mutual beneficial exchange' in international trade (see, for instance, Krugman 1993, p. 24). While one can debate whether the principle of comparative advantage is actually a theory instead of a veiled truism, the doctrine of free trade, which is derived from this principle, remains to many in the profession a 'moral Law,' as Keynes (1933 [1982]) described it, to which all mainstream economists must profess their faith.

In contrast, influenced by the experience of the Great Depression, Keynes felt that, while the logic of the classical/neoclassical theory seemed irrefutable, reality seemed to have little to do with the principle of comparative advantage and, therefore, the latter ought not to serve as a basis for public policy. This is because, in essence, he argued, '[a] considerable degree of international specialization is necessary in a rational world in all cases where it is dictated by wide differences of climate, natural resources, ... and density of population. But ... most modern mass-production processes can be performed in most countries and climates with almost equal efficiency' (Keynes 1933 [1982], p. 238). Because of this fact that production of tradable goods can be produced 'with almost equal efficiency' in practically all countries, the only meaningful principle that may apply is that of absolute labor cost advantage, which means that a high-wage region may well find itself without jobs under free trade unless regulations prevent price competition from low wage imports. The free trade solution would hardly be a Pareto optimum outcome, when one portion of the population benefits potentially from the lower prices while another portion of the population faces the prospect of unemployment, unless wages fall, which, as Keynes had surmised in The General Theory (1936), could result in the population of both trading countries being worse off at the macroeconomic level by merely exacerbating the problem of unemployment (Milberg 2002, pp. 241-242).

Because of the inappropriateness of this 'moral law,' Keynes (1933 [1982]) recommended what became a famous dictum that was partly embedded in the early postwar Bretton Woods system: '... let goods be homespun whenever it is reasonably and conveniently possible; and, above all, let finance be primarily national' (ibid., p. 236), thereby opting for a system in which both commodity trade and footloose corporations (and their financial backers) remained regulated, including international stabilization measures, such as buffer stock arrangements to deal with 'the epidemic of intermittent effective demand' (Keynes 1942 [1974], p. 306).

The object of this article is to offer a heterodox/Keynesian critique of the free trade doctrine and to distinguish the idealized world of free trade from the reality of export-led growth (ELG), as it became embedded in the NAFTA model. Indeed, the latter was sold primarily on the basis of competition for scarce jobs (Krugman 1993, p. 25) within what are fundamentally demand-constrained economies, in which even macroeconomic 
policies become subjected to the logic of ELG. The article then looks at the ELG experience before and after the original CUSFTA and NAFTA and shows how the logic of ELG leads to macro outcomes that are quite different from what the simplified free trade doctrine would envisage.

\section{A KEYNESIAN/HETERODOX CRITIQUE OF THE DOCTRINE OF FREE TRADE AND THE PRINCIPLE OF COMPARATIVE ADVANTAGE}

The principle, or 'law,' of comparative advantage is often presented as the 'bread and butter' of economics. In its simplest form it states that, as long as there are relative differences in productivity across countries, if more (or all) of one's human resources are pooled into producing what they are relatively more efficient at producing, 'free trading' nations will produce more of everything and thus will be better off through trade liberalization and specialization. As Keynes argued, its logic seems irrefutable but, as a theory about the real world, it was problematic and misleading. The theory predicts two broad 'macroeconomic' outcomes normally referred to as the static gains from trade: (1) overall productivity or output per head among trading countries will rise as a result of trade specialization; and, as corollary, (2) exports as well as overall gross domestic output within the whole trading bloc will rise with trade liberalization. Consequently, the welfare of these trading nations would be enhanced through increased production and consumption both in the aggregate and on a per capita basis. As we shall see, with North American trade liberalization, one may legitimately argue that neither of these predictions turned out to be quite correct. But before discussing what did happen with increasing trade liberalization, let us summarize briefly some important heterodox critiques of the free trade doctrine.

The principle of comparative advantage rests on a good number of questionable assumptions, some of which are highly problematic. The most well-known are that: (1) the theory assumes full employment (even though free trade is generally promoted by policy-makers as a policy to generate scarce private sector jobs), with the explicit assumption that trade occurs between two trading entities called 'nations' rather than between firms; (2) there is the problem of the composition and evolution of technology and output; and (3) there is the assumption that the market mechanism will generate trade balances. All, ultimately, as we shall see, have to do primarily with assuming away the macroeconomic problem of effective demand.

Let us begin with the first problem. It is well known already from David Ricardo that the theory makes sense not only by assuming that labor and capital are immobile internationally but also by assuming that an economy is resting at a full employment/full capacity level of output, so that an increase in the production of one good can be done only at the expense of some other good (Felipe and Vernengo 2002-2003; Schumacher 2013). However, as soon as we dispense with the full employment assumption to fit the real world in which unemployment and unused capacity are the norm, it is no longer comparative advantage but the principle of absolute advantage that rules (Shaikh 2007). This would mean, therefore, that one country (or region) could find itself without jobs while another country (or region) could be producing most of the tradable goods. Yet policy-makers who promoted free trade, whether it was in favor of the original CUSFTA or NAFTA, argued for a 'win-win' situation whereby both consumers (because of lower prices) and workers (because of the creation of more jobs in the export sector) would benefit in the three trading 
countries, as well as gain the added positive 'political' outcome of reducing economic pressure to migrate, particularly in the case of illegal migration from Mexico (Blecker 2003; Ruiz Durán 2003). However, this is a completely erroneous prediction in a world ruled by absolute advantage, unless one abstracts from the problem of effective demand. As highlighted by Lavoie (2014, ch. 7), this is because in these models they confuse, among other things, trading nations with trading firms. Firms take decisions not on the basis of some ideal theory of comparative advantage but always on the basis of absolute cost advantage. Hence, if firms can profitably increase their market shares by moving their production facilities to another place where there are significant cost advantages, they will do so, thereby leaving another region without jobs. In the traditional analysis, the problem of effective demand is omitted, since increasing unemployment may well turn out to be the eventual outcome that, as we shall see, cannot be removed through downward wage flexibility for all the trading regions combined.

The second problem has to do with the nature and evolution of production activities over time. There is the well-known problem of the composition of output in the global value chain, for instance, as addressed in the Singer-Prebisch thesis pertaining to the evolution of the terms of trade between primary producers and manufactured goods over time and the increasing vulnerability that specialized regions can face, which, for instance, Keynes was seeking to address with his buffer stock proposal (Keynes 1942 [1974]). But there is also another problem often raised by heterodox economists. This second criticism was already revealed in the second quote from Keynes (1933 [1982], p. 238) above. If firms could locate themselves anywhere because of 'almost equal efficiency' in production, then, as we said, in the traditional model, absolute advantage prevails. However, as soon as one leaves the comfort of the pure static model of trade, trade policy that is guided by comparative advantage becomes even more problematical and doubtful. This arises in dynamic industries facing increasing returns to scale or declining unit costs, which is often the case, for instance, in manufacturing (see Kaldor 1981). Ever since Friedrich List in the mid nineteenth century and Chang (2002) in recent times, this observation has been used to defend various forms of protectionism, with tariff and protectionist non-tariff measures having been important instruments in the hands of the 'developmental state' historically (Pérez Caldentey 2008). However, even abstracting from the classic 'infant industry' question, the mere unpredictability of the evolution of technology and unit costs over time, as well as the evolution of demand, would advise against the pure static free trade solution, since countries could find themselves locked in downside industries facing shrinking world demand. Again, this ultimately is reducible primarily to a problem of demand and loss of jobs, arising because of the significance of absolute advantage in the competitive process over market shares and market domination.

The third problem is a twofold one relating to the so-called automaticity of the equilibrating mechanisms at work in dealing with both trade imbalances and the macroeconomic imbalances that could ensue. This is not so much because, as some critics would argue, in a modern world dominated by large transnational corporations, competitive free market conditions would hardly prevail. Rather, and more importantly, if under free trade there is a tendency for an inordinate growth of unemployment in one country (because of problems of absolute advantage), the traditional neoclassical solution would be either that the country allows its currency to depreciate (under a floating exchange rate system) or allows wages and other factor costs to fall via domestic deflation (Robinson 1949 [2009]). The problem with such options has been well known since the 1930s. The latter (or second) policy option of implementing domestic 
austerity through wage deflation simply 'beggars thy own workers' through lower wages, while concomitantly exporting the unemployment abroad. The first option, instead, 'beggars thy neighbour's workers' by exporting the unemployment through exchange rate adjustment. Eventually, the outcome of competitive wage deflation or competitive exchange rate devaluation would be merely to shrink overall effective demand and raise unemployment for all the trading countries combined. However, this first option is somewhat more complex in terms of outcome since it would depend on the strength of the price elasticity of exports and imports by fulfilling the so-called Marshall-Lerner condition. The recognition of this technical nuance via exchange rate adjustment does not suggest that fixed exchange rates would be preferred to floating exchange rates and that a commitment to the former would be desirable. There is some evidence that suggests that floating exchange rates are preferred because they impose less of a constraint on policy-makers to pursue expansionary macroeconomic policy (see Bougrine and Seccareccia 2004). This is so even though competitive depreciation in esse is hardly a suitable mechanism to address the problem of macroeconomic imbalances, such as high unemployment in a country, as it becomes merely an international power game of musical chairs, in terms of who is going to be stuck with the high or rising unemployment.

While there are many other heterodox criticisms of the merits of the free trade solution based on the principle of comparative advantage (as listed by Schumacher 2013), the focus here is on the critical Keynesian problem of unemployment. To conclude: just as competitive deflation of wages domestically cannot remove the imbalance caused by the lack of labor demand, neither can this be done in an international economy through either a cut in wages and/or exchange rate depreciation. In a world dominated by conditions of absolute advantage, the Achilles' heel of classical and neoclassical theory remains the problem of effective demand.

\section{FREE TRADE, EXPORT-LED GROWTH, AND THE PERVERSE MACROECONOMIC ROLE OF THE STATE}

Because of the incapacity of neoclassical theory to recognize the problem of effective demand, numerous Keynesian and post-Keynesian writers from R.F. Harrod in the 1930 s to A.P. Thirlwall in the 1970 s rejected the neoclassical supply-constrained models in favour of demand-induced models, for instance, of the foreign trade multiplier. Hence, in these Keynesian models of ELG, increases in exports give rise to multiplier/ accelerator effects that would lead to positive expansion for all trading countries, since the higher exports will eventually be balanced by higher imports. A good example is Thirlwall's (1979) analysis of the dynamized version of the Harrod foreign trade multiplier used to explain early post-World War II growth among industrial countries.

However, none of these writers ever theorized about the role of the state within these ELG models of liberalized trade, especially as this process of trade liberalization took place during the post-Bretton Woods era. In their analysis, the role of the state was seen as that of an exogenous 'neutral' entity with separate 'autonomous spending' behavior comparable to that of the export sector or, at best, as a Keynesian state committed to high employment, by dealing with problems of unemployment by means of activist macroeconomic policies, as had happened during the early postwar period. It would seem that at no time, for instance, did these early writers seriously consider the possible connection between rising exports and the macroeconomic policy behavior of the state, such as fiscal tightening, in which the austerity policy of the state becomes endogenous 
to the ELG strategy itself. Indeed, no one ever considered that the state would actually become the instrument to ensure some form of competitive deflation in order to succeed in what, ironically, the early advocates of free trade, going back to Adam Smith and David Ricardo, most feared and rejected, which was a most pernicious neo-mercantilist form of ELG strategy that emerged during the post-Bretton Woods period of trade liberalization. Yet, despite the rhetoric regarding the removal of tariff barriers, a hybrid neo-mercantilism was largely the outcome of this whole process of trade liberalization that began during the early post-Bretton Woods era.

Indeed, it can be argued that what actually emerged is merely a new perverse form of mercantilism in which countries compete for scarce jobs by implementing austerity so as to succeed in the international competitiveness game. As has been pointed out elsewhere (Seccareccia 2007; 2014), since the end of the Bretton Woods era we have seen the evolution of a world system in which the international hegemony or core country, the United States, has been running a chronic trade deficit with the rest of the world, and with this deficit being counterbalanced by a large constellation of countries, even outside of the North American context, seeking to achieve trade surpluses based on a strategy of ELG. Furthermore, instead of amassing precious metals, as was done during the old mercantilist era of the seventeenth and eighteenth centuries, the more successful countries in the ELG game have been accumulating virtual or paper 'reserves' in the financial centres of the imperial core (see Ocampo 2007-2008). This was done by maintaining austerity policies domestically that suppress wage growth by having internal consumption demand growing less quickly than total production, thereby securing structural trade surpluses with the core importing country in the world. This would explain why, in contrast to the early postwar quarter-century, over this post-Bretton Woods period (beginning in the 1970s) world trade has been growing more quickly than overall world output, while, at the same time, the global trend growth of output has slowed down sharply from the previous earlier postwar Bretton Woods era. Because of proximity and the obvious economic and political hegemony of the US, North America is a case par excellence, revealing these growing perverse neo-mercantilist structural asymmetries that have emerged internationally since the 1970s, with the US being the predominant source of external demand for Canadian and Mexican goods.

However, before discussing the nature of the evolution of macroeconomic policy, let us look at some stylized facts regarding what happened during the post-trade liberalization era, which includes CUSFTA and NAFTA in the North American context. Because of the difficulty of obtaining comparable data for such long historical periods for Mexico, Table 1 offers a bird's eye view of the growing problem of unemployment, which actually began immediately after the collapse of the Bretton Woods system only for Canada and the United States. It is clear from this table that the post-1973 period can be characterized by a significant slowdown in the Harrodian natural rate of growth, which was caused by a growing long-term problem of effective demand and rising unemployment in both countries. Whether one starts with 1974 as a breakpoint or 1989 (with CUSFTA) or 1994 (with NAFTA), what is obvious is that there is a persistence of slow growth and significantly higher long-term unemployment throughout most of the post-Bretton Woods period. Moreover, it should be obvious (as has been argued elsewhere, see Seccareccia 2013) that this growing unemployment problem could not have resulted from some persistent 'supply-side' phenomenon of, say, growing labor supply or a speed-up in the rate of technical change, since both labor force growth and productivity growth had been declining in comparison to the same factors in the 1946-1973 period.

What appears to be more revealing as to a possible cause of this rising unemployment and growing problem of effective demand is to be found in Table 2, which provides data 
Table 1 Historical statistics of Canada and the United States on labor force growth, average labor productivity growth of the total business sector, and overall unemployment rate, various sub-periods, 1946-2013

\begin{tabular}{lccc}
\hline & Labor force growth (\%) & Productivity growth (\%) & Unemployment rate (\%) \\
\hline Canada & & & \\
$1946-1973$ & 2.4 & 4.0 & 4.6 \\
$1974-2013$ & 1.8 & 1.3 & 8.3 \\
$1989-2013$ & 1.3 & 1.2 & 7.1 \\
1994-2013 & 1.4 & 1.3 & \\
United States & & & 4.8 \\
1948-1973 & 1.6 & 3.2 & 6.5 \\
$1974-2013$ & 1.4 & 1.9 & 6.1 \\
1989-2013 & 1.0 & 2.1 & 6.0 \\
1994-2013 & 0.9 & 2.2 & \\
\hline
\end{tabular}

Source: Canada: Statistics Canada, Historical Statistics of Canada (Second Edition), 1983), Series D134-145 and F241-249, and CANSIM series V1409153, V2062810 and V206814; United States: Economic Research Division, Federal Reserve Bank of St. Louis and US Bureau of Labor Statistics.

Table 2 Real GDP growth and percentage share of exports for the consolidated three North American countries, 5-year averages, 1961-2010

\begin{tabular}{lcc}
\hline Period & GDP growth $(\%)$ & Share of exports $(\%)$ \\
\hline $1961-1965$ & 5.2 & 6.3 \\
$1966-1970$ & 4.2 & 6.6 \\
$1971-1975$ & 3.0 & 8.1 \\
$1976-1980$ & 3.9 & 9.9 \\
$1981-1985$ & 3.2 & 10.1 \\
$1986-1990$ & 3.2 & 10.3 \\
$1991-1995$ & 2.5 & 11.8 \\
$1996-2000$ & 4.4 & 13.8 \\
$2001-2005$ & 2.5 & 12.7 \\
$2006-2010$ & 0.9 & 14.2 \\
\hline
\end{tabular}

Source: World Bank DataBank - World Development Indicators.

from 1961 on real GDP growth, as well as the percentage share of exports out of GDP, when the three NAFTA countries were regrouped into one combined area. What can be observed is that, during the $1960 \mathrm{~s}$ - a period in which the share of exports was gravitating at around 6.5 percent of GDP for the combined North American region - output was growing at a relatively high postwar rate. Over the past decade, however, this share of exports has reached more than double its earlier percentage share for the combined NAFTA countries, while real GDP growth has instead completely bottomed out. The only significant exception to this negative relation is during the latter half of the $1990 \mathrm{~s}$, when there was a virtuous cycle of growth (at over 4.4 percent) combined with a rising share of exports. The 1996-2000 period was the only 5-year period during which the optimistic predictions of the orthodox free trade model seem to be substantiated by the facts. This was a period when there was actually an increasing output and productivity growth moving concomitantly with an increasing share of GDP that was being exported mostly from Canada and Mexico to the US, and which coincided with 
the first years of NAFTA. In the context of the whole period, however, it's an aberration, which perhaps may have a lot to do with the exuberant expectations and internal dynamics of the so-called 'new economy' during the Clinton era! Consequently, in order to shed better light on the matter, these same observations grouped in Table 2 are also displayed individually in the form of a scatter diagram (Figure 1) for the complete 50-year period. A simple regression line has been fitted to the data in the diagram, which indicates a significant negative relation, even though there is obvious dispersion around it.

The stylized facts for the last 50 years offer some rather revealing prima facie evidence about how trade and economic growth are associated in North America. This was a period during which the trade shares rose consistently on average across the three NAFTA countries, with a sharp acceleration during the 1970s, as there was increasing trade liberalization after the collapse of the Bretton Woods system, and then again in the 1990s. On the other hand, overall growth rates continued to decline significantly. Except for a few outliers (mainly in the late 1990s), overall demand among the NAFTA countries was growing ever more slowly (from around a 4.5 percent average in the 1960s to around a 1.5 percent average for the first decade of the twenty-first century), with a concomitant long-term rise in the unemployment rate and long-term decline in the growth rate of productivity (as seen for Canada and the US in Table 1 and Figure 2). While the free trade model would have predicted that the growth in exports should have exceeded overall growth of the North American economies, on the basis of the principle of comparative advantage one would hardly have predicted the dramatic long-term slowdown of that combined growth rate as well as the decline in aggregate productivity growth, say, for Canada and the US, namely two of the three important trading nations that became progressively more integrated commercially throughout the period, especially during the post-1989 era. On average, growth should have been rising in relation to its long-term trend pari passu with the rise in exports, and not the reverse, as was actually observed.

Moreover, one obtains the same general portrait when looking at productivity growth data (see Figure 2). As measured, for instance, in terms of output per hour, it shows a significant decline by the late 1970s and remains low for all countries,

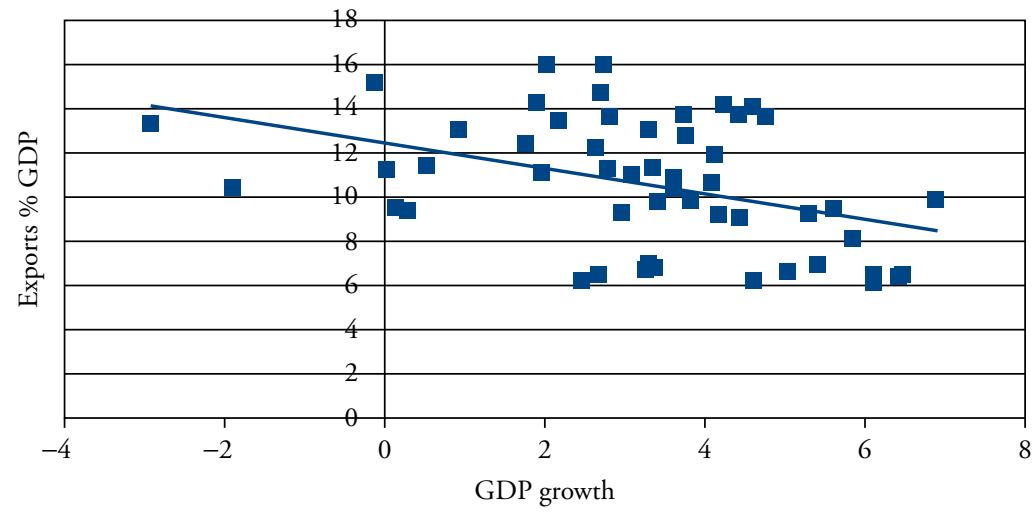

Source: World Bank DataBank - World Development Indicators.

Figure 1 Scatter diagram of real GDP growth and percentage share of exports, combined North American countries, annual observations 1961-2010 


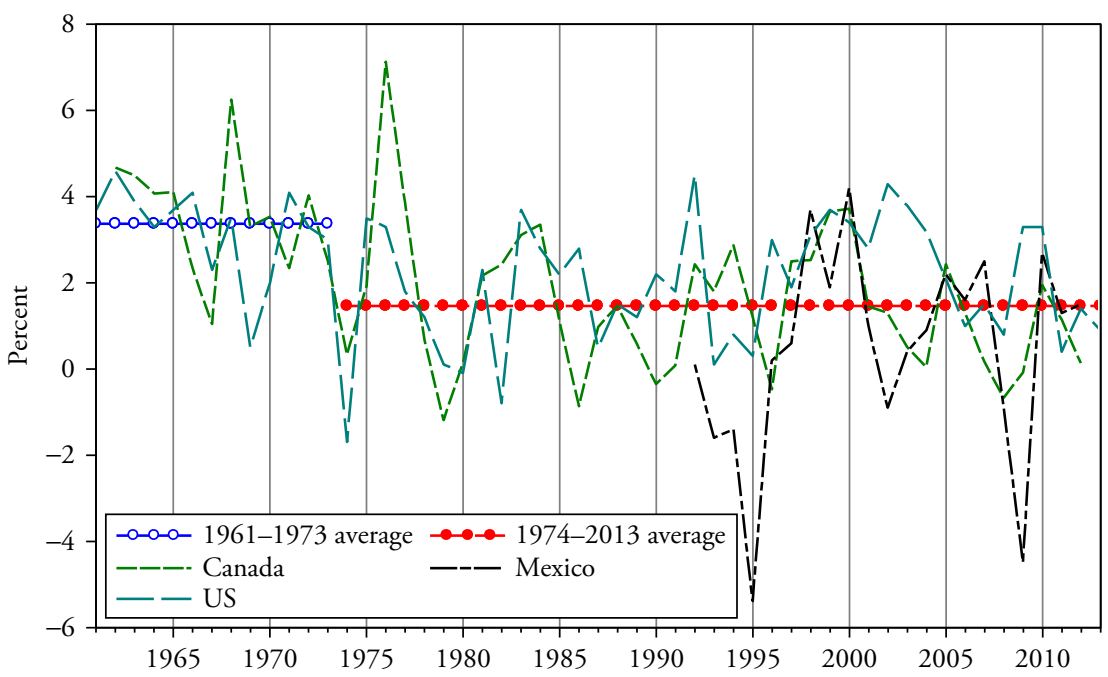

Sources: OECD iLibrary; Statistics Canada, CANSIM series V41712898; and US Bureau of Labor Statistics series PRS84006092.

Figure 2 Evolution of growth of output per hour in the three NAFTA countries, 1961-2013, and simple averages for the two sub-periods (annual observations)

including Mexico, which displays more erratic fluctuations, particularly in the downward direction. Unfortunately, because of the inability of finding a consistent series on output per hour for Mexico for the complete period (the Mexican series starts only in 1992), I did not reproduce a figure similar to Figure 1 with the share of exports and the productivity growth data on the axis. However, the fact that productivity growth was generally slowing down would hardly be consistent with the free trade model, since none of these countries saw any acceleration in productivity growth, with the exception of the late 1990s. On the other hand, it would be seemingly more consistent with the post-Keynesian view and Verdoorn's law, with growth in aggregate demand slowing down as a consequence of the neo-mercantilist application of the ELG model in North America.

\section{WHY WERE THE GROWING EXPORTS ACCOMPANYING TRADE LIBERALIZATION ASSOCIATED WITH A DECLINE IN OVERALL GROWTH AND WHAT ANALYTICAL FRAMEWORK WOULD BE CONSISTENT WITH THESE BROAD OBSERVATIONS?}

Although one could point to many possible disparate non-trade-related reasons for the slower growth since the end of the Bretton Woods era, such as the oil price shocks of the mid to late 1970s, the 'dot.com' crisis of 2000-2001, the financial crisis and ensuing Great Recession in 2008-2009, and so on, it would be difficult to make the case that increasing trade liberalization had no negative effect on domestic wage growth and thus on domestic consumption growth, and that, moreover, this 'great moderation' chilling effect would have been of a long-term nature that was common to the last 4 decades. 
While those other ad hoc factors could explain potentially some of the dispersion around the regression line in Figure 1, there was a clear underlying relation in that figure which was compatible with one obvious explanation and common to the 4 decades since the 1970s: the international competitiveness pressures resulting from the increasingly liberalized trade (with initially greater impetus for tariff reductions coming from the earlier General Agreements on Tariff and Trade (GATT)), which was accelerated and reinforced institutionally with CUSFTA and NAFTA in the North American context and then by the World Trade Organization (WTO) internationally also by the 1990s.

This pressure probably took two important forms. In the first, there may have been direct labor market pressure on wages resulting from the growing penetration of international competition as tariff and non-tariff barriers had been increasingly removed previously under the Tokyo and Uruguay rounds of GATT. Even neoclassical economists would agree with this, especially as these international pressures impacted on the less-skilled labor force on at least two of the more developed economies of what would become the NAFTA region by 1994 . There has been much debate among labor market economists about the growing significance of low-wage casual employment as the low-skilled manufacturing jobs disappeared in Canada and the US partly as a result of the increasing trade liberalization. Much of the evidence suggests that the mere removal of the tariff in the case of CUSFTA and NAFTA did not have a strong impact on both earnings and employment. For example, in the case of Canada, one of the early studies by Gaston and Trefler (1997) found that there was little effect on earnings and that the CUSFTA tariff cuts accounted for no more than 15 percent of Canadian job losses, whereas other factors, such as the Bank of Canada's fight against inflation through high real interest rate policy and the ensuing recession of the early 1990s, explained about 85 per cent of the job losses at the time. These employment losses were, however, predominantly among less-skilled workers (Beaulieu 2000). Similar results of little effect can be found in numerous other writings, such as Trefler (2004). If this was so, then this brings us to the more indirect effect arising from the macroeconomic policies that were adopted by governments as they engaged in the neo-mercantilist strategy of ELG. The story is, therefore, more complex because we also need to 'endogenize' the behavior of government policy in the context of growing trade liberalization. In fact, the conduct of macroeconomic policy and a particular macroeconomic policy mix was an important indirect factor which undoubtedly contributed to the compression of labor cost growth generally and further reinforced the problem of long-term unemployment.

Let us begin with monetary policy. By the late 1970s, in reaction to the high inflation rates that ensued from the oil price shocks, we observe central banks, especially in Canada and the US, adopting Volcker-style monetarism (as shown graphically in Figure 3), by beginning to raise real interest rates to unprecedented historical levels in these countries so as to combat the inflation. This policy entailed stabilizing real interest rates at those very high levels that slowed down growth and raised unemployment rates, which, as can be seen from the figure, was pursued for almost 2 decades until very early in the twenty-first century, but with some bifurcation between Canada and the US only in the early 1990s. These harsh high real interest rate measures were pursued by central banks until the inflation rates of the three North American economies converged after NAFTA to relatively low levels associated with the so-called 'great moderation' of the post-NAFTA era. Despite the fact that these were often cloaked in either monetarist jargon or later in neo-Wicksellian guise (via inflation targeting), in actual fact these anti-inflation measures were merely a specific form of incomes policy whose underlying political motivation driving policy-makers was 


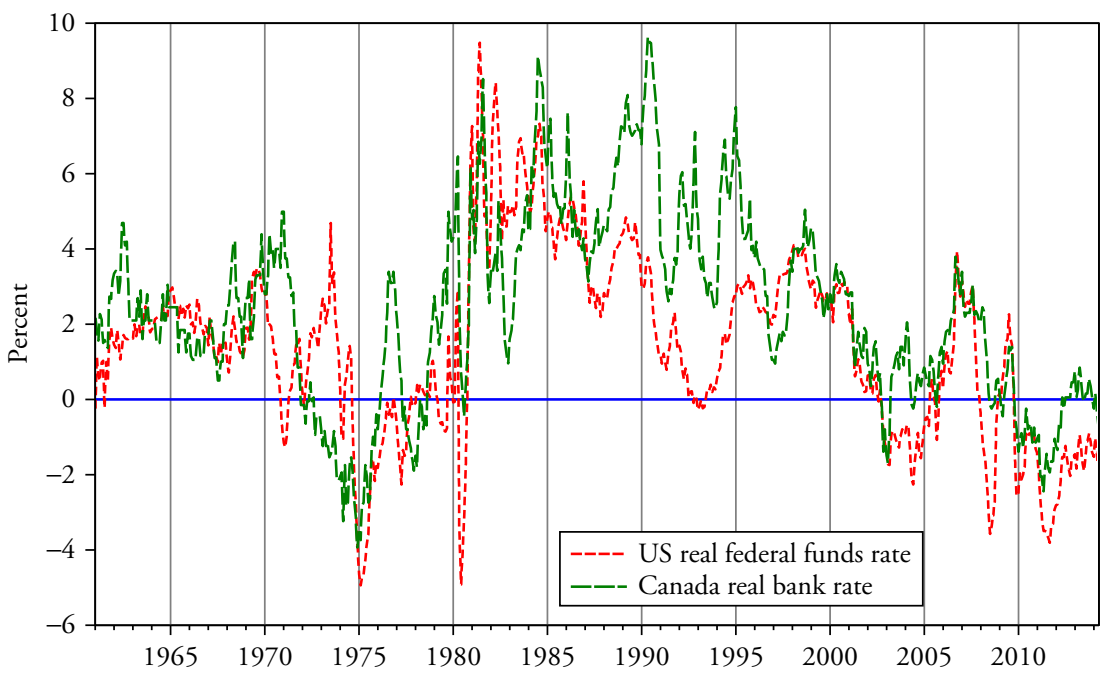

Sources: Statistics Canada, CANSIM V122530 and V41690973 and US Federal Reserve series H15/H15/ RIFSPFF_N.M and Bureau of Labor Statistics series CUUR0000SA0.

Figure 3 Evolution of monetary policy: central-bank-administered real interest rates, the bank rate of the Bank of Canada and the federal funds rate of the United States Federal Reserve, 1961-2014 (monthly observations)

usually a neo-mercantilist one in terms of cost competitiveness (Seccareccia and Lavoie 2010).

To understand the full effect of these macroeconomic measures, in support of the competitiveness logic, taken especially after the adoption of NAFTA, one must consider the overall macro policy mix. The fiscal side began to play a major role in reinforcing the restrictive monetary policy that had been in place, but mostly in the late 1990s and during the early 2000s, as displayed in Figure 4 for both Canada and the US. A useful measure of the discretionary behavior of the fiscal authorities is the cyclically adjusted primary balance as an indicator of fiscal policy impulses since, unlike the former, actual budget balances are directly affected by monetary policy (via the interest payments on the public debt) as well as by the workings of automatic stabilizers. During the early NAFTA era, the fiscal authorities (in both Canada and the US) were seeking to implement massive austerity measures, as can be observed from the estimated cyclically adjusted primary balances in Figure 4, measured as a percentage of GDP. Canada shows the strongest commitment to fiscal austerity, as even during the financial crisis the federal government was still seeking to maintain cyclically adjusted primary surpluses. The logic behind this neo-mercantilist policy is similar to the presumed structure of causality specified in the 'twin deficits' arguments normally recounted by orthodox economists (for a critical assessment, see Seccareccia and Sharpe 1994). Instead of budget deficits generating trade deficits, now a fiscal surplus (through its deflationary effect) can supposedly also generate a trade surplus. Needless to say, as the Godley equations would suggest, this could only happen depending on the behavior of the household and business sector balances, and it could work for one country but not for all three countries combined that are mostly trading with each other, since they cannot all generate trade surpluses among 


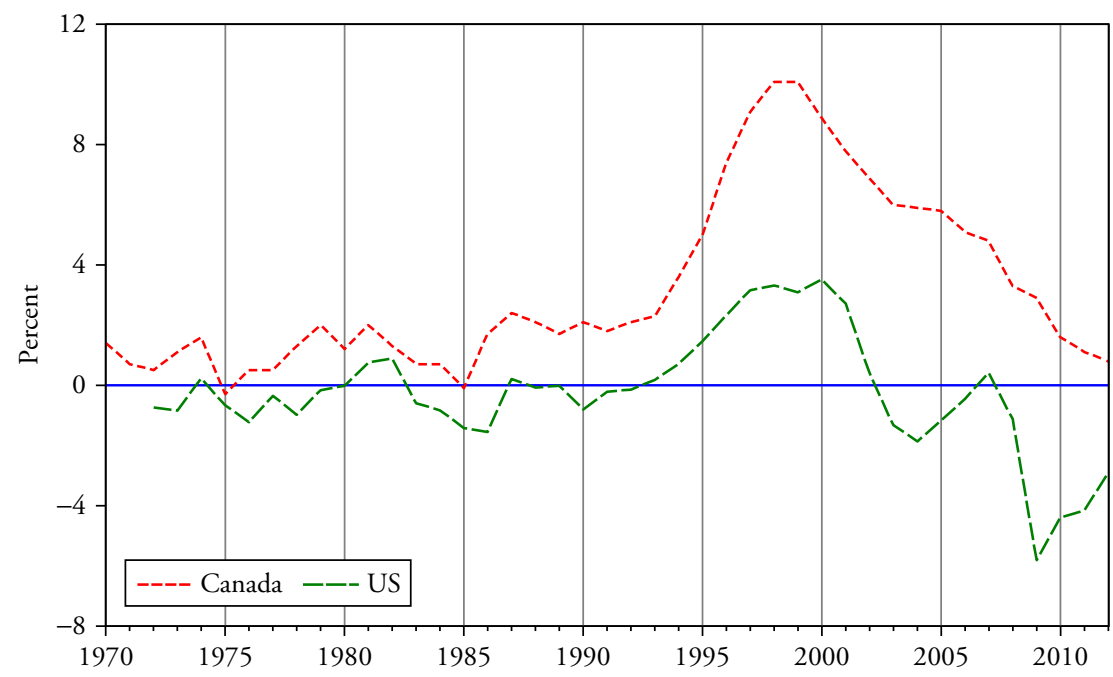

Sources: Congressional Budget Office, 'Historical Budget Data' (January 2012), and Congressional Budget Office, 'The Effects of Automatic Stabilizers on the Federal Budget as of 2013' (March 2013); Canada Federal Department of Finance, Fiscal Reference Tables, http://www.fin.gc.ca/frt-trf/2013/frt-trf-13-eng.asp.

Figure 4 US Federal and Canadian total cyclically-adjusted primary government balances as percentage of GDP, 1970-2012 (annual series)

themselves simultaneously! In fact, as can be seen, because of force majeure, especially on account of the financial crisis, the Bush administration in the US had already begun to move away from targeting fiscal surpluses after September 11, 2001, as they moved progressively away from the imposition of strong doses of fiscal austerity pursued by the previous Clinton administration.

Under the growing pressures that resulted particularly from the financial crisis, the directions of both fiscal and monetary policy eventually did take a significant U-turn from the era of the 'great moderation' that had resulted from the neo-mercantilist logic that took hold especially after the adoption of CUSFTA and NAFTA. While the growing trade liberalization did play an important role in mitigating wage growth in all three NAFTA countries during that era, those nations with the strongest neo-mercantilist policies of wage moderation were able to benefit in this 'beggar thy neighbor' policy. Hence it is not surprising that a country like Canada, which imposed greater fiscal and monetary austerity than the US, was also the country that was seemingly more successful initially in its hybrid neo-mercantilist policy. For instance, as shown in Figure 5, the evolution of the relative compensation of the total business sector between Canada and the US was such that the timing of the relative decline coincides almost completely with the adoption of CUSFTA in 1989 (the gray section of the graph), which was further reinforced by a dramatic depreciation of the Canadian dollar throughout the 1990s. What eventually hurt Canada was the reversal of the evolution of the Canada-US exchange rate. This reversal eliminated the favorable exchange-rate-adjusted wage gap, as the Canadian dollar became a petro-currency and started to rise some 5 years before the financial crisis as Canada's manufacturing exports began to suffer more and more from the effects of the Dutch disease (Blecker and Seccareccia 2014; Seccareccia 2014). Nowadays, 


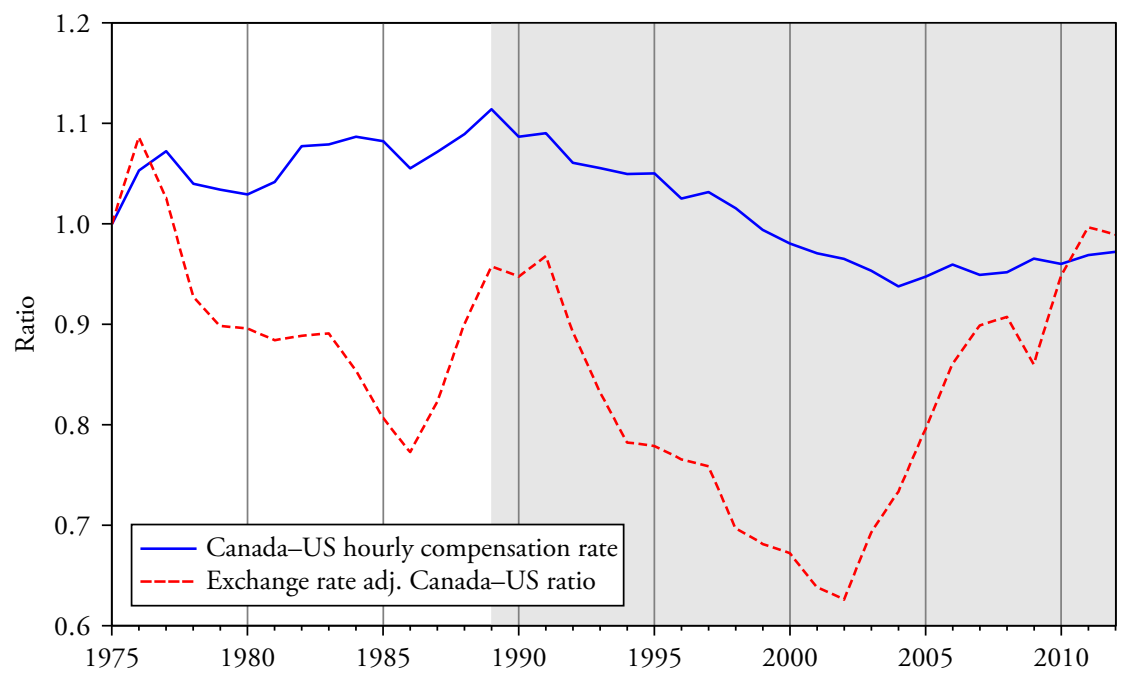

Sources: Statistics Canada, CANSIM series V37426, V1409158, and V720734 and US Bureau of Labor Statistics series PRS84006103.

Figure 5 Evolution of Canada-US hourly compensation, total business sector, $1975=1.00,1975-2012$ (annual observations)

policies of low inflation and wage moderation remain in force but without the prospects of significant economic growth, as governments seek to maintain a lid on inflation primarily through renewed fiscal austerity.

\section{CONCLUDING REMARKS}

Growing international trade through greater trade liberalization has not delivered the 'goods,' if by 'goods' we mean accelerating growth in output and productivity at full employment. Instead of the questionable 'moral law' of free trade, we have discovered what may be dubbed a 'Keynes Law,' under which, as more countries open up to international trade by dismantling regulatory trade structures that protected local communities from the market, the greater is the proliferation of deflationary tendencies because of competitive pressures whose effects are to compress domestic demand and by implication world demand. Moreover, we have seen that, instead of the 'invisible hand' of the market, it has been to an even greater extent the 'visible hand' of the state through its monetary and fiscal policies that has imparted a deflationary bias by compounding the effect of the 'wage moderation' arising from international competitiveness pressures. What we have been witnessing is a type of perverse neo-mercantilist policy of ELG that began with the breakdown of the Bretton Woods system. This policy structure was later enshrined under NAFTA, and subsequently became generalized internationally, as large economic blocs have become engaged in this mercantilist game, in some cases with very dire consequences, such as within the eurozone.

The CUSFTA and the NAFTA experiences over the last quarter-century offer policymakers important lessons that forcefully bring us back to Keynes. Keynes was not really 
opposed to trade liberalization. What he feared were the reasons why free trade is promoted. Remember the famous quote at the beginning of this article from 1933 about the necessity for a 'considerable degree of international specialization ... in a rational world.' Indeed, if the reason for trade in a fully-employed economy is because Canada, say, cannot efficiently grow avocados and because Mexico, say, cannot easily produce maple syrup, then the classical theory of comparative advantage makes a lot of sense that would undeniably promote greater welfare. However, if the main reason for freer trade is because the latter is offered as a solution to the problem of scarcity of jobs for which workers in both countries are competing, then that is not a morally acceptable principle, since such a policy can lead to dire social consequences, as footloose corporations go inexorably where wages are lowest and where they reap the highest rewards. Hence, free trade in a world in which all countries are pursuing full-employment policies surely would not be a problem. It is only when trade becomes an instrument not only of mercantilist predation but also of relative impoverishment of communities that it becomes objectionable. What is needed is a new NAFTA that can encourage the free circulation of goods and that, furthermore, ties the governments of all three countries to a genuine full-employment objective by means of Keynesian macroeconomic policies. Twentyfive years of CUSFTA and twenty years of NAFTA substantiate this. Neoliberal trade policies have merely offered progressively lower growth (even for a country like Mexico), and have led to flat or even declining real wages and rising income inequality, at least for a good chunk of that 'free trade' area, namely Canada and the US.

\section{REFERENCES}

Beaulieu, Eugene (2000), 'The Canada-U.S. Free Trade Agreement and Labour Market Adjustment in Canada,' Canadian Journal of Economics, 33(2), 540-563.

Blecker, Robert A. (2003), 'The North American Economies after NAFTA: A Critical Appraisal,' International Journal of Political Economy, 33(3), 5-27.

Blecker, Robert and Mario Seccareccia (2014), 'Would a North American Monetary Union Protect Canada and Mexico against the Ravages of "Dutch Disease"? A Post-Financial Crisis Perspective,' in G. Epstein, T. Schlesinger, and M. Vernengo (eds), Banking, Monetary Policy and Political Economy of Financial Regulation, Essays in the Tradition of Jane D'Arista, Cheltenham, UK and Northampton, MA: Edward Elgar, pp. 171-202.

Bougrine, Hassan and Mario Seccareccia (2004), 'Alternative Exchange Rate Arrangements and Effective Demand: An Important Missing Analysis in the Debate over Greater North American Monetary Integration,' Journal of Post Keynesian Economics, 26(4), 655-677.

Chang, Ha-Joon (2002), Kicking Away the Ladder: Development Strategy in Historical Perspective, London: Anthem Press.

Felipe, Jesus and Matias Vernengo (2002-2003), 'Demystifying the Principles of Comparative Advantage: Implications for Developing Countries,' International Journal of Political Economy, 32(4), 49-75.

Gaston, Noel and Daniel Trefler (1997), 'The Labour Market Consequences of the Canada-US Free Trade Agreement,' Canadian Journal of Economics, 30(1), 18-41.

Kaldor, Nicholas (1981), 'The Role of Increasing Returns, Technical Progress and Cumulative Causation in the Theory of International Trade and Economic Growth,' Économie Appliquée, 34(4), 593-617.

Keynes, John Maynard (1933 [1982]), 'National Self-Sufficiency,' The Yale Review, 22(4), 755-769, reprinted in D. Moggridge (ed.), 1982, The Collected Writings of John Maynard Keynes, Vol. 21, London: Macmillan, pp. 233-246.

Keynes, J.M. (1936), The General Theory of Employment, Interest and Money, London: Macmillan. 
Keynes, John Maynard (1942 [1974]), 'The International Control of Raw Materials,' Journal of International Economics, 4(3), 299-315.

Krugman, Paul (1993), 'What Do Undergrads Need to Know about Trade?' American Economic Review, Papers and Proceedings, 83(2), 23-26.

Lavoie, Marc (2014), Post-Keynesian Economics: New Foundations, Cheltenham, UK and Northampton, MA: Edward Elgar.

Milberg, William (2002), 'Say's Law in the Open Economy: Keynes's Rejection of the Theory of Comparative Advantage,' in S. Dow and J. Hillard (eds), Keynes, Uncertainty and the Global Economy, Aldershot, UK: Edward Elgar, pp. 239-253.

Ocampo, José Antonio (2007-2008), 'The Instability and Inequities of the Global Reserve System,' International Journal of Political Economy, 36(4), 71-96.

Pérez Caldentey, Esteban (2008), 'The Concept and Evolution of the Developmental State,' International Journal of Political Economy, 37(3), 27-53.

Robinson, Joan (1949 [2009]), The Problem of Full Employment, Chicago: G. Langer.

Ruiz Durán, Clemente (2003), 'NAFTA: Lessons from an Uneven Integration,' International Journal of Political Economy, 33(3), 50-71.

Schumacher, Reinhard (2013), 'Deconstructing the Theory of Comparative Advantage,' World Economic Review, 2, 83-105.

Seccareccia, Mario (2007), 'Critical Macroeconomic Aspects of Deepening North American Economic Integration,' in R. Grinspun and Y. Shamsie (eds), Whose Canada? Continental Integration, Fortress North America, and the Corporate Agenda, Montreal/Kingston: McGillQueen's University Press, pp. 234-258.

Seccareccia, Mario (2013), 'Budgetary Deficits and Overhanging Public Debt: Obstacles or Instruments to Full Employment? A Kaleckian/Institutionalist Perspective,' Journal of Economic Issues, 47(2), 437-443.

Seccareccia, Mario (2014), 'Modelos de desarrollo económico basados en producción de básicos: lecciones del pasado y del presente de la experiencia canadiense,' in E. Correa and J. Deniz (eds), Estrategias Primario-Exportadoras en un Mundo Global, Mexico: Miguel Angel Porrua (forthcoming).

Seccareccia, Mario and Marc Lavoie (2010), 'Inflation Targeting in Canada: Myth versus Reality,' in G. Fontana, J. McCombie, and M. Sawyer (eds), Macroeconomics, Finance and Money: Essays in Honour of Philip Arestis, London: Palgrave Macmillan, pp. 35-53.

Seccareccia, Mario and Andrew Sharpe (1994), 'Canada's Competitiveness: Beyond the Budget Deficit,' Économies et Sociétés, 28(1), 275-300.

Shaikh, Anwar (2007), 'Globalization and the Myths of Free Trade,' in A. Shaikh (ed.), Globalization and the Myths of Free Trade: History, Theory and Empirical Evidence, London: Routledge, pp. 50-68.

Thirlwall, Anthony P. (1979), 'The Balance of Payments Constraint as an Explanation of International Growth Rate Differences,' Banca Nazionale del Lavoro Quarterly Review, 32(128), 45-53.

Trefler, Daniel (2004), 'The Long and the Short of the Canada-U.S. Free Trade Agreement,' American Economic Review, 94(4), 870-895. 